\title{
Direitos e deveres em tempos de fluxos migratórios: uma conversa sobre a obra Estranhos à nossa porta com alunos do PLAc no CEFET-MG
}

\section{○ \\ OPEN ACCESS

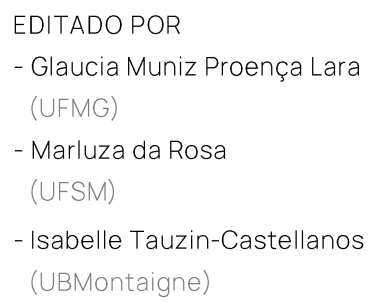

\section{Adriana do Carmo FIGUEIREDO (D)}

Centro Federal de Educação Tecnológica de Minas Gerais (CEFET-MG)

RESUMO

Este estudo tem como objetivo apresentar um relato de experiência sobre a nossa participação no Programa Português como Língua Estrangeira (PLE) oferecido pelo Centro Federal de Educação Tecnológica de Minas Gerais (CEFET$\mathrm{MG})$, por meio de uma palestra ministrada no Curso de Português como Língua de Acolhimento (PLAc). Esse relato será analisado à luz de categorias específicas da Análise do Discurso $(\mathrm{AD})$ de vertente francesa, tais como os conceitos de narrativas de vida, como propõe Machado (2016), as noções de hiperenunciador e aforização, de acordo com Maingueneau (2008, 2010), e as relações entre identidades e imaginários socioculturais, conforme teoriza Charaudeau (2015). A metodologia é de natureza qualitativa e emprega uma abordagem transdisciplinar com discussões entre o Direito, a $\mathrm{AD}$, a Teoria Social de Jürgen Habermas (2000, [1985]), sobre a noção de "reificação da sociedade", e a proposta sociológica de Zygmunt Bauman (2017 [2016]) desenvolvida em sua obra Estranhos à nossa porta. O corpus analisado é composto por fragmentos da obra de Bauman, trechos da legislação vigente sobre Direitos Humanos e relatos de alunos participantes do PLAc. Como resultado, identificamos a relevância das narrativas de vida para reflexões sobre identidades e para o enfrentamento de conflitos gerados em situações de fluxos migratórios. Observamos, ainda, a importância do entrecruzamento teórico transdisciplinar como estratégia de condução discursiva nas aulas de conversação do PLAc. 


\section{REVISTA DA ABRALIN}

RESUMEN

Este estudio tiene como objetivo presentar un relato de experiencia sobre nuestra participación en el Programa de Portugués como Lengua Extranjera (PLE) ofrecido por el Centro Federal de Educación Tecnológica de Minas Gerais (CEFET-MG), a través de una conferencia impartida en el Curso de Portugués como Lengua de Acogimiento (PLAc). Este relato será analizado a la luz de categorías específicas del Análisis del Discurso (AD) de vertiente francesa, por intermedio de los conceptos de narrativas de vida, en conformidad con Machado (2016), las nociones de hiperenunciador y aforización, según Maingueneau (2008, 2010), y las relaciones entre identidades e imaginarios socioculturales, como teoriza Charaudeau (2015). La metodología es de naturaleza cualitativa y emplea un enfoque transdisciplinario con discusiones entre el Derecho, el AD, la Teoría Social de Jürgen Habermas (2000, [1985]), sobre la noción de "reificación de la sociedad", y la propuesta sociológica de Zygmunt Bauman (2017 [2016]) desarrollada en su libro Extraños llamando a la puerta. El corpus analizado consta de fragmentos de la obra de Bauman, extractos de la legislación vigente sobre Derechos Humanos y relatos de estudiantes participantes del PLAc. Como resultado, hemos identificado la relevancia de las narrativas de vida para las reflexiones sobre identidades y para el enfrentamiento de los conflictos generados en situaciones de flujos migratorios. También hemos observado la importancia del cruce teórico transdisciplinario como estrategia discursiva en las clases de conversación del PLAc.

\section{PALAVRAS-CHAVE}

Fluxos migratórios. Narrativas de vida. Estranhamento. Direitos Humanos. Teoria social.

\section{PALABRAS CLAVE}

Flujos migratorios. Narrativas de vida. Extrañamiento. Derechos Humanos. Teoría Social.

\section{Introdução}

O Programa Português como Língua Estrangeira (PLE) oferecido pelo Centro Federal de Educação Tecnológica de Minas Gerais (CEFET-MG) tem se destacado nas ações afirmativas voltadas para pessoas em fluxos migratórios. Esse programa é resultado de uma ação conjunta entre a Secretaria de 


\section{REVISTA DA ABRALIN}

Relações Internacionais (SRI) e o Departamento de Linguagem e Tecnologia (DELTEC) do CEFETMG. Os encontros de conversação, juntamente com as palestras e consultorias jurídicas, são alguns exemplos dessas ações que contam com a participação de vários profissionais.

Atualmente, a equipe do PLE é composta por servidores da SRI e do DELTEC, 2 bolsistas de Pósgraduação e 8 bolsistas de graduação, que possuem bolsas da própria instituição. Ademais, há diversos voluntários atuantes no Programa que, na atual gestão, é coordenado pelas professoras Luciana Aparecida Silva de Azeredo (DELTEC) e Maria Cristina Ramos de Carvalho (SRI).

O objetivo principal do PLE é articular as suas diversas atividades, iniciadas em 1997, e com forte expansão e regularidade a partir de 2016, com as demandas de pessoas em situação de imigração. Dessa forma, o PLE tem recebido estudantes de diversificados perfis, tais como refugiados, portadores de visto humanitário e imigrantes em situação de vulnerabilidade social. É válido destacar que esse Programa está alinhado às ações relacionadas ao ensino, à pesquisa, à extensão e ao processo de internacionalização do ensino da Língua Portuguesa e Cultura Brasileira, aspectos importantes que têm promovido grande impacto social e reconhecimento do Programa no Brasil e no exterior.

Com base no último Relatório Parcial de Cumprimento de Objeto referente ao ano de 2020, disponibilizado pela SRI, em 4 de março de $2021^{1}$, o curso de Português como Língua de Acolhimento (PLAc) integra uma das ações do PLE. O PLAc foi criado com o propósito de atender a alunos estrangeiros que geralmente viviam em situação de vulnerabilidade social em seus países de origem. Esses alunos ainda enfrentam dificuldades no Brasil. Dessa forma, juntamente com as atividades de aperfeiçoamento linguístico, os encontros do PLAc abordam demandas que fazem parte do cotidiano do corpo discente. Entre elas, destacam-se entrevistas de emprego, debates sobre hábitos culturais e outros tópicos, como palestras e consultorias jurídicas, que facilitem a inclusão do aluno estrangeiro na sociedade brasileira.

Participaram das atividades do PLAc, segundo o relatório supracitado, 28 alunos no nível intermediário, 10 alunos no nível básico e 8 alunos no curso preparatório para o Celpe-Bras, ministrado com essa abordagem do Português como Língua de Acolhimento. É importante esclarecer que os alunos que participam desse curso preparatório já possuem algum conhecimento da língua portuguesa. Em síntese, nessa atividade, houve a participação de 46 alunos de nacionalidades diferentes.

Entre as ações do PLE, há também o curso Preparatório Celpe-Bras do CEFET-MG, conhecido como Pré-PEC G, curso que consiste na preparação dos alunos estrangeiros para o Exame CelpeBras. Tais alunos, ao ingressarem nesse Preparatório, não possuem nenhum conhecimento da língua portuguesa. Assim, o corpo discente desse curso é composto por alunos-candidatos ao Programa Estudantes Convênio de Graduação (PEC-G) que procuram o CEFET-MG, porque em seus países de origem não há postos aplicadores do referido exame.

É importante esclarecer que a certificação do Exame Celpe-Bras é um dos pré-requisitos para que os estudantes possam ingressar no PEC-G. Assim, ao preencherem o requisito, eles se tornam

\footnotetext{
${ }^{1}$ Tivemos acesso às informações desse relatório por comunicações via e-mail com a equipe de conversação PLE/PLAc do CEFETMG, em 4 de agosto de 2021.
} 


\section{REVISTA DA ABRALIN}

alunos de graduação em uma instituição de ensino superior no Brasil. Esse curso é oferecido pelo CEFET-MG desde 2017. Dados do referido relatório apontam que a turma de 2020 foi composta por 10 alunos de 6 países diferentes: Haiti, Benim, Gabão, Honduras, Costa do Marfim e Guiné Equatorial. Devido à pandemia, a partir do dia 16 de março de 2020, as aulas foram realizadas pelo Ensino Remoto Emergencial (ERE) com 2 horas de duração e diversas atividades assíncronas.

Dessa forma, 56 alunos no total (PLAc e Pré-PEC G) foram atendidos pelo Programa Português como Língua Estrangeira do CEFET-MG, segundo o Relatório. É válido mencionar que a adoção do ERE possibilitou novas formas de ensino-aprendizagem com diferentes participantes e representou ainda economia nos gastos referentes aos deslocamentos para o local das aulas. Por meio das salas virtuais, tivemos encontros com alunos de diferentes perfis e com outras pessoas interessadas no projeto.

Assim, os alunos do PLE foram atendidos por uma equipe multidisciplinar com importante potencial humanizador para o alcance dos objetivos, alicerçados especialmente na inclusão social dos estrangeiros na realidade brasileira. Acreditamos que a colaboração de voluntários de outras instituições e convidados de diferentes segmentos da sociedade civil é um diferencial para as propostas do Programa, pautadas também na compreensão do sistema de direitos e garantias sociais. É precisamente essa perspectiva de voluntariado, na condição de professora e consultora jurídica, que nos motivou para a escrita deste artigo, em razão das observações que fizemos ao longo de 4 (quatro) anos de colaboração com as atividades do PLE.

Isso posto, destacamos que o objetivo deste texto é relatar uma experiência recente que tivemos no Programa Português como Língua Estrangeira do CEFET-MG, por meio de atividades desenvolvidas no PLAc. Em 5 de agosto de 2021, fui ${ }^{2}$ convidada para conduzir uma conversa ${ }^{3}$ com os alunos estrangeiros a respeito da obra Estranhos à nossa porta, de Zygmunt Bauman (2017 [2016]). O convite foi feito para que eu pudesse conduzir esse encontro na condição de advogada constitucionalista, consultora e analista de discurso. As interlocuções oriundas dessa conversa, algumas citações da obra de Bauman e trechos da legislação compõem o corpus deste estudo, que será analisado por meio de categorias específicas da Análise do Discurso (AD) de vertente francesa, em diálogo com alguns aportes do discurso jurídico relativo ao fenômeno da migração.

\footnotetext{
${ }^{2}$ Peço-lhes permissão para o emprego da $1^{a}$ pessoa do singular em alguns momentos deste relato de experiências, dada a singularidade das narrativas que compõem este relato. Enfatizamos que algumas atividades do PLAc são feitas mediante convite a profissionais de diferentes áreas. No dia 5 de agosto de 2021, o convite me foi feito, para que eu pudesse prestar uma consultoria jurídica aos alunos estrangeiros sobre temas que provocaram inquietudes no corpo discente durante as aulas do PLE. Estiveram presentes, na sala virtual, a equipe de coordenação e os voluntários do PLAc. Além dos alunos estrangeiros, outras pessoas compareceram ao evento para a observação da atividade. As identidades dos participantes foram preservadas em conformidade com as orientações do Comitê de Ética do CEFET-MG e da Secretaria de Relações Internacionais (SRI).

${ }^{3}$ Neste estudo, empregaremos os termos conversa, conversação e palestra para qualificar o evento do dia 5 de agosto de 2021. Essa ação se faz necessária, porque o evento se deu em um formato diferenciado. Em alguns momentos, tive que atuar como condutora de uma conversa, já que uma das propostas desse encontro era a realização de uma atividade de conversação para o aprimoramento do português como língua estrangeira. No entanto, em outros momentos do evento, tive que atuar como palestrante, porque a consultoria jurídica sobre a apatridia foi feita na modalidade expositiva.
} 


\section{REVISTA DA ABRALIN}

Zygmunt Bauman tem sido considerado um dos mais importantes sociólogos da atualidade, pois a sua produção intelectual aproxima aspectos teóricos da sociologia com o universo atualizado e cotidiano da vida em sociedade, por meio de uma linguagem acessível à compreensão do público leitor, de modo geral. Sua obra Estranhos à nossa porta, publicada originalmente em 2016, apresenta uma importante discussão a respeito do posicionamento das nações frente à crescente presença de refugiados em seus territórios.

Embora o sociólogo polonês busque destacar o cenário dos refugiados oriundos especialmente do Oriente Médio e da África em direção ao bloco econômico europeu, Estranhos à nossa porta trouxe notável contribuição para as nossas conversas no PLAc, pois nos permitiu estabelecer relações entre direitos, deveres e políticas públicas direcionadas ao "estranho/estrangeiro" que chega ao território brasileiro e se abre para o aprendizado da língua portuguesa e da cultura representativa da nossa sociedade.

Para alicerçar o arcabouço teórico dessa conversa com os alunos imigrantes do CEFET-MG, recortamos alguns aspectos da $\mathrm{AD}$ que integram o nosso procedimento metodológico-analítico neste estudo: o conceito de narrativas de vida, como propõe Machado (2016), será empregado para a análise discursiva dos relatos dos alunos, conduzidos durante a conversa sobre a obra Estranhos à nossa porta. Essas narrativas serão analisadas por meio das contribuições da Semiolinguística, especialmente, à luz das reflexões de Charaudeau (2015) sobre as relações entre identidades e imaginários socioculturais. As noções de enunciação, aforização e hiperenunciador, conforme teoriza Maingueneau $(2008,2010)$, nos auxiliarão na compreensão de vozes discursivas evocadas por tratados internacionais e legislações internas que versam sobre algumas situações de migração. A Teoria Social de Jürgen Habermas (2000, [1985]) nos auxiliará na compreensão do conceito de invisibilidade, por meio de sua categoria intitulada "reificação da sociedade".

Como resultado desse relato de experiências, destacamos a importância dos estudos discursivos como fio condutor das conversas que tivemos com os estrangeiros, pois, quando foram interpelados por mim, durante a palestra/conversação, eles puderam colocar em prática a capacidade linguísticodiscursiva de autoanalisar as relações entre língua e identidades culturais como aspectos importantes para a superação do sentimento de estranhamento provocado por situações reais características dos processos migratórios. Observamos, ainda, a relevância da abordagem transdisciplinar para os estudos linguísticos, uma vez que o diálogo entre linguagem, direitos humanos e sociedade se mostrou profícuo para a construção dessa autoanálise durante a conversação com os alunos do PLAc.

\section{Igualdade, invisibilidade e reificação: aquecendo a nossa conversa}

A conversação do dia 5 de agosto de 2021, intitulada "Direitos e deveres em tempos de fluxos migratórios: uma leitura da obra Estranhos à nossa porta de Zygmunt Bauman", ocorreu pelo Ensino 


\section{REVISTA DA ABRALIN}

Remoto Emergencial (ERE), no horário das 19h às 20h. Estiveram presentes 4 alunos estrangeiros ${ }^{4} \mathrm{e}$ 3 ouvintes brasileiros que se interessaram pela temática. Também estavam no auditório virtual as professoras coordenadoras das atividades do PLAc, Patrícia Rodrigues Tanuri Baptista e Fernanda Cristina Sant'Ana Dusse, além da voluntária Priscilla Stephanie Guimarães, responsável pela abertura da sala e recepção dos participantes. A minha participação foi como condutora da conversa e palestrante, ao mesmo tempo, pois o evento se apresentou com especificidades em seu formato metodológico, como afirmamos.

A conversa iniciou-se com a leitura de alguns versos do poema "Igualdade", de autoria de Silvia Danizete Pereira Barbosa ${ }^{5}$, extraído da obra Vozes: eu ele nós: literatura e direitos humanos. Um dos alunos estrangeiros (participante A) fez a leitura da poesia e, posteriormente, destacou os seguintes enunciados:

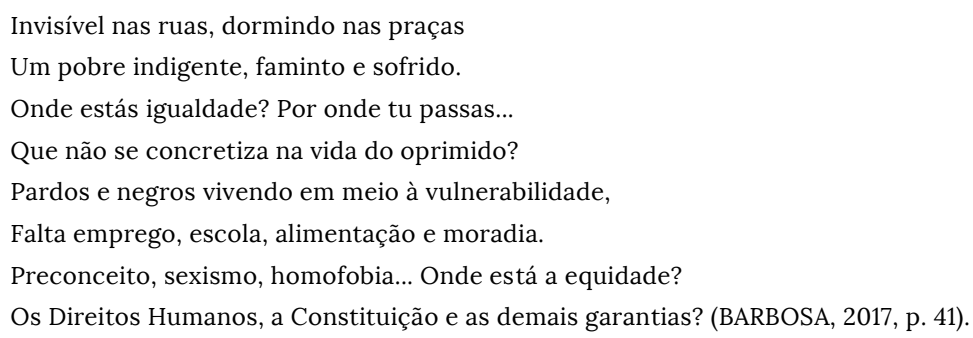

O sentido atribuído ao sintagma "invisível nas ruas" trouxe o termo "invisibilidade" como marco introdutório da conversa. Foi nesse instante que alguns aspectos específicos da Análise do Discurso começaram a se destacar no debate, entre eles, ressaltamos a força da enunciação poética que, naquele momento de leitura em voz alta, se tornou uma espécie de "[...] pivô da relação entre a língua e o mundo" (MAINGUENEAU, 2016, p. 193). Pensar a noção de "invisibilidade" nos conduziu a uma reflexão mais ampla sobre a representação de fatos na natureza do enunciado e nos fez indagar ainda se o enunciado não constituiria por si mesmo um fato, ou "[...] um acontecimento único definido no tempo e no espaço" (MAINGUENEAU, 2016, p. 193).

Na interpretação do Participante A, tal como foi explicitada para o auditório, muitos imigrantes se sentem algumas vezes como pessoas invisíveis, mas, ao mesmo tempo, essas pessoas são destacadas por sua natureza diferente daquela que compõe a sociedade para a qual se deslocaram. A reflexão sobre a invisibilidade nos permitiu ainda pôr em cena o funcionamento da língua em um processo de interlocução necessário aos propósitos do Curso de Português como Língua de Acolhimento (PLAc), conforme se extraem dos objetivos do Programa:

\footnotetext{
${ }^{4}$ Para fins de preservação das identidades dos participantes estrangeiros, não indicaremos os nomes reais dos citados e lhes atribuiremos letras maiúsculas, quando forem evocados neste estudo. De acordo com o termo de autorização de uso de dados emitido pelo CEFET-MG, as identidades e suas respectivas caracterizações deverão ser mantidas em sigilo, em conformidade com o Comitê de Ética da instituição e com as orientações da Secretaria de Relações Internacionais (SRI). Ressaltamos que essas ações também visam a preservar os direitos personalíssimos dos participantes, protegidos pela Constituição Federal de 1988 e pelo CAPÍTULO II Dos Direitos da Personalidade, nos termos do art. 11 e seguintes do Código Civil de 2002.
}

${ }^{5}$ Na ocasião da publicação da referida obra, a autora era aluna do Mestrado em Educação Tecnológica do CEFET-MG. 


\title{
REVISTA DA ABRALIN
}

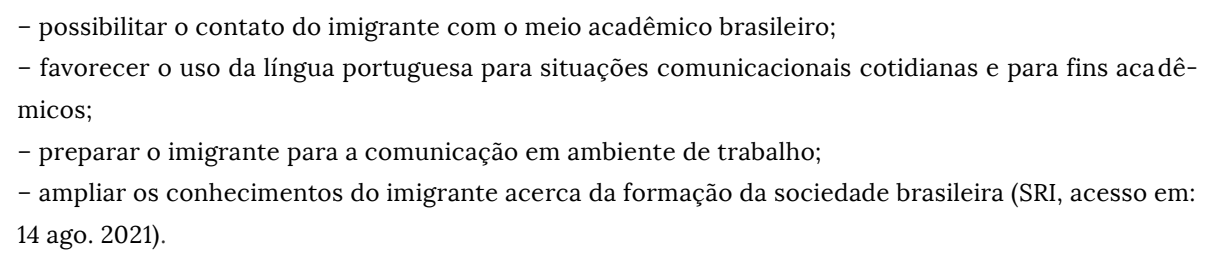

Sem dúvida, o valor ilocutório dessa conversa com os alunos imigrantes que estudam no CEFETMG nos permitiu, como linguistas, colocar em evidência a dimensão reflexiva da atividade linguageira, o que, de certa forma, nos conduziu a indagações sobre a referencialidade que o enunciado ("invisível nas ruas") comporta sobre os seres que habitam territórios em fenômenos de fluxos migratórios. Ao pensarmos a representação de fatos na dimensão do enunciado, nossa conversa foi direcionada para um fragmento da obra de Bauman:

\begin{abstract}
Michel Agier - talvez o mais incisivo, coerente e, hoje, de longe o mais experiente e perceptivo pesquisador preocupado com o destino de mais de 200 milhões de pessoas (globalmente) deslocadas sugere que a "política migratória" se destina a "consolidar uma divisão entre duas grandes categorias mundiais cada vez mais reificadas: de um lado, um mundo limpo, saudável e visível; de outro, o mundo dos 'remanescentes' residuais, sombrio, doente e invisível" (BAUMAN, 2017, p. 60, aspas do original).
\end{abstract}

O excerto entrecortado revela uma situação discursiva interessante para aprofundarmos a reflexão sobre a noção de invisibilidade que se tornou o tema introdutório da nossa conversa com os alunos imigrantes. Bauman, na condição de sujeito comunicante e enunciador, conforme categorias explicitadas por Charaudeau (1983) ${ }^{6}$, evoca a voz enunciativa de um terceiro discursivo, o pesquisador Michel Agier, com o intuito de esclarecer epistemologicamente a gravidade do problema em torno do destino de cerca de 200 milhões de pessoas deslocadas por variados espaços globais. Com essa abordagem, o fragmento citado indica a voz enunciativa de um sociólogo-cidadão incorporado pela figura intelectual de Bauman que, também, denuncia a existência de uma divisão entre duas categorias de mundo: uma que se refere à sociedade integrante do mundo visível; e outra que integra o lado residual, enfermo e sombrio desse mundo. A essa segunda categoria, é atribuída a noção de invisibilidade.

Nesse contexto de invisibilidade, a voz discursiva baumaniana também nos convida a refletir sobre a ideia de "categorias mundiais reificadas", com base na percepção interdiscursiva do pesquisador Michel Agier, a respeito da política migratória global (AGIER, 2011, p. 3 apud BAUMAN, 2017, p. 60). A noção de mundo social reificado tem sido discutida por nós em algumas produções acadêmicas, entre elas, destacamos nossa tese doutoral defendida em 8 de outubro de 2020, pelo Programa de Estudos Linguísticos da Universidade Federal de Minas Gerais (PosLin/UFMG).

\footnotetext{
${ }^{6}$ A respeito dessas categorias, recordamos o famoso quadro dos circuitos do ato de linguagem, em que Charaudeau (1983) observa a presença de dois espaços: no espaço externo, o linguista francês aponta a ação de dois sujeitos (seres sociais) - comunicante e interpretante. No espaço interno, por sua vez, ele indica a presença de dois sujeitos (seres de fala) - enunciador e destinatário. Em algumas situações discursivas, as figuras do comunicante e do enunciador se imiscuem e, de forma semelhante, essa fusão também pode acontecer entre o suposto destinatário e o sujeito interpretante.
} 


\section{REVISTA DA ABRALIN}

Jürgen Habermas (2000, [1985]), em sua obra O discurso filosófico da Modernidade, teoriza sobre a proposta de uma razão nos limites de sua precariedade. Segundo o autor frankfurtiano, existe um impulso social que "[...] serve apenas para propagar universalmente a dominação da razão calculadora, já ancorada antropologicamente nas estruturas do trabalho" (HABERMAS, 2000, p. 315). Esse impulso conduz ao que a teoria social define como "reificação da sociedade".

O conceito de "reificação" pode ser compreendido, de forma sintética, como uma espécie de coisificação da ação. Trata-se do processo em que a condição de subjetividade se torna um elemento coisificado, e tudo passa a ter uma expressão que se configura pela noção de mercadoria. A tendência à "[...] reificação da sociedade remonta a épocas arcaicas e estende-se, para além do capitalismo, até o futuro do socialismo burocrático, que cumprirá o testamento do processo histórico-universal de desencantamento" (HABERMAS, 2000, p. 316).

Nesse sentido, Habermas, inspirado pelas ideias de Berger e Luckmann (1966), destaca:

Reificação é a concepção dos produtos humanos como se fossem algo que não produtos humanos: condições naturais, sucessão de leis cósmicas ou manifestações de uma vontade divina. Reificação implica que o homem é capaz de esquecer a própria autoria do mundo humano e, além disso, que a dialética entre os produtores humanos e os seus produtos perdeu-se para a consciência. Um mundo reificado é, por definição, um mundo desumanizado. O ser humano vivencia-o como faticidade alheia a si, um opus alienum, sobre o qual ele não tem nenhum controle, e não como opus proprium da sua atuação produtiva (BERGER; LUCKMANN, 1966, p. 95 apud HABERMAS, 2000, p. 112-113, itálicos do original).

É nesse contexto de reificação da sociedade que nos deparamos com situações de invisibilidade, em que emerge o mundo sombrio e residual dos "remanescentes", como destacou Bauman (2017). Esse mundo parece ser desenhado por um processo coletivo e consciente de dominação que implica a natureza do outro excluído, por meio de uma racionalidade de natureza subjetiva. Segundo Habermas (2000), a razão subjetiva gera uma certa desconfiança em função de uma categoria que denomina como "agente colonizador". O desejo de dominar a natureza e instrumentalizar a cultura parece ser o impulso para a criação daquilo ou daqueles que são deslocados para a marginalidade ou para a categoria dos remanescentes. Nas palavras de Habermas (2000), a racionalidade humana deveria se colocar em uma posição histórica de autocrítica,

[...] a partir da perspectiva do outro excluído por ela; mas, então, torna-se indispensável um ato último de auto-reflexão que se suplante a si mesmo, mais exatamente, um ato de razão em que o lugar do genitivo subjetivo deveria ser ocupado pelo outro da razão. A subjetividade como auto-relação do sujeito cognoscente e agente apresenta-se na relação binária da auto-reflexão (HABERMAS, 2000, p. 429, preservamos a grafia original).

É precisamente nas dificuldades de constituição de uma razão que deveria se deixar criticar, com base na perspectiva do outro excluído, que nos parece situar um provável diagnóstico das políticas migratórias que consolidam as divisões de mundo, como sinalizadas por Bauman (2017). Ao assumir incondicionalmente a cultura herdada por agentes colonizadores, a sociedade se deixa submeter a sistemas de poder que colonizam comportamentos e determinam condutas. Por isso, assistimos a um corpo social que adere à ideia de que a entrada de estrangeiros em nossos territórios 


\section{REVISTA DA ABRALIN}

gera um problema de segurança social. Essa problemática suscita, entre outros aspectos, o sentimento concreto de desumanização que

[...] abre caminho à exclusão da categoria de seres humanos legítimos, portadores de direitos, e leva, com nefastas consequências, à passagem do tema da migração da esfera da ética para a das ameaças à segurança, prevenção e punição do crime, criminalidade, defesa da ordem e, de modo geral, ao estado de emergência comumente associado à ameaça de agressão e hostilidades militares (BAUMAN, 2017, p. 57).

Vale destacar que, desse imaginário hostil da insegurança e da suposta ameaça social, brota a noção de estranhamento, como se "estranhos à nossa porta" insistissem na abertura da passagem aos novos territórios e no consequente projeto de inclusão social. O sentimento e as condições de estranhamento foram importantes aspectos debatidos com os alunos estrangeiros do PLAc, no CEFET-MG, ocasião em que tivemos a oportunidade de observar, analisar e registrar alguns relatos, conforme explicitaremos no tópico 3 deste artigo. A conversa sobre a invisibilidade, por sua vez, gerou novas abordagens com base nos Direitos Humanos e na noção de apatridia, como demonstraremos no tópico 2 .

\section{Invisibilidade e apatridia: violações aos direitos humanos}

Antes de analisar os relatos dos nossos alunos estrangeiros do CEFET-MG, gostaríamos de tecer breves comentários sobre os desdobramentos provocados pela noção de invisibilidade durante a nossa conversa sobre os "estranhos à nossa porta". Nesse sentido, destacamos que a nossa proposta de conversação ganhou um contorno jurídico e um tom mais formal, quando fizemos uma breve palestra sobre a situação da apatridia, no dia 5 de agosto de $2021^{7}$, momento em que buscamos refletir sobre as condições sociais, culturais e jurídicas das pessoas consideradas apátridas.

Embora Bauman não analise com detalhes essa categoria de pessoas em fluxos migratórios, o sociólogo fala dos "miseráveis", os "sem pátria recém-chegados" (BAUMAN, 2017, p. 12), e faz uma longa narrativa a respeito dos refugiados, de modo geral, e da situação de invisibilidade que assola certas circunstâncias de migração. Dessa forma, as observações de Bauman nos conduziram a novas reflexões a respeito dessa temática e, por isso, evocamos a categoria dos apátridas para a nossa

\footnotetext{
${ }^{7}$ Esclarecemos que a palestra sobre a apatridia, ministrada no dia 5 de agosto de 2021, compõe um conjunto de ações propostas por nós desde 2017, em que auxiliamos o PLE com consultorias jurídicas sobre temas diversos, especialmente, sobre aqueles que se referem ao sistema de direitos e garantias fundamentais. No $1^{\circ}$ semestre de 2021, por exemplo, falamos sobre injúria racial, xenofobia, violência doméstica, entre outros temas. No $2^{\circ}$ semestre de 2021, optamos por esclarecer temas que constam da Lei de Migração de 2017 (Lei n 13.445/17), como a definição dos apátridas e o posicionamento da República Federativa do Brasil diante dessa situação migratória. Já estamos organizando os próximos encontros, em que falaremos sobre os chamados "residentes fronteiriços" e sobre a política migratória brasileira.
} 


\title{
REVISTA DA ABRALIN
}

conversação com os estrangeiros. Em continuação, segue uma síntese da exposição que fizemos sobre as pessoas apátridas.

A apatridia é uma especificidade dos processos migratórios e ocorre por diversas razões, entre elas, ressaltamos o contexto discriminatório contra minorias na legislação nacional, equívocos ou falhas em reconhecer todos os residentes de um determinado país como cidadãos, quando acontecem processos de secessão de Estados, por exemplo, e um desses se torna independente. Também se verifica situação de apatridia quando há conflitos legislativos entre países.

Estatísticas recentes ${ }^{8}$ indicam que o Brasil abrigou cerca de 16 pessoas reconhecidas formalmente como apátridas, segundo dados oficiais. Vejamos:

\begin{abstract}
O Ministério da Justiça e Segurança Pública reconheceu 16 imigrantes como apátridas desde a nova lei de Migração, em vigor desde 2017. Destes, dois foram reconhecidos em 2018, sete em 2019 e outros sete em 2020. Dos 16, quatro se naturalizaram brasileiros em 2018 e 2019. Os apátridas reconh ecidos passam a ter autorização de residência no Brasil por prazo indeterminado, sendo-lhes assegurado o exercício de todos os direitos e garantias, em condição de igualdade com os nacionais, conforme a Constituição Federal e pela Lei de Migração, excetuado o direto ao voto. Ao terem registrada a residência no Brasil, os apátridas passam a ter direito à Carteira de Registro Nacional Migratório, documento que facilita a vida civil do portador que passa a ter condições de acesso a emprego e a serviços públicos e bancários. Como forma de cumprir o compromisso internacional de erradicação da apatridia, a legislação brasileira oferece um trâmite de naturalização diferenciado, havendo uma redução do prazo de residência exigido para obtenção da nacionalidade brasileira (Ministério da Justiça e Segurança Pública, acesso em 5 set. 2021).
\end{abstract}

É válido esclarecer que, no Brasil, de acordo com a Lei nº 13.445/17 e o Decreto n 9.199/17, a definição de apátrida está relacionada à

[...] pessoa que não seja considerada como nacional por nenhum Estado, segundo a sua legislação, nos termos da Convenção sobre o Estatuto dos Apátridas, de 1954, promulgada pelo Decreto $\mathrm{n}^{\circ} 4.246$, de 22 de maio de 2002, ou assim reconhecida pelo Estado brasileiro" (BRASIL, 2017).

Segundo o Alto Comissariado das Nações Unidas para os Refugiados (ACNUR), "cerca de quinze milhões de pessoas - ou seja, o correspondente à população de um país médio - podem ser apátridas" (NAÇÕES UNIDAS BRASIL, acesso em: 19 ago. 2021). No entanto, a situação de apatridia é ainda desconhecida, ou pouco estudada, e nem sempre há esclarecimentos sobre a dimensão e o alcance dessa problemática. Nesse sentido, o apagamento de um vínculo com a pátria

[...] é uma condição degradante e enfraquecedora que influencia quase todos os aspectos da vida de uma pessoa. Aqueles que não são reconhecidos como cidadãos de um país não podem, com frequência, matricular-se na escola, trabalhar legalmente, possuir imóveis, casar-se ou viajar. Podem ter dificuldade em ser hospitalizados e não conseguir abrir uma conta bancária ou receber uma pensão. Se são vítimas de roubo ou de estupro, podem ver-se impossibilitados de apresentar queixa [apresentar notícia-crime à polícia], porque, aos olhos da lei, não existem. Muitas vezes, não têm sequer um nome

\footnotetext{
${ }^{8}$ Nesse sentido, cf.: https://www.gov.br/mj/pt-br/assuntos/noticias/ministerio-da-justica-e-seguranca-publica-reconhece16-estrangeiros-como-apatridas. Acesso em: 5 set. 2021.
} 


\section{REVISTA DA ABRALIN}

reconhecido oficialmente. Os apátridas encontram-se em todos os cantos do mundo, tanto nos países desenvolvidos como nos países em desenvolvimento (ONU BRASIL, acesso em: 19 ago. 2021).

Dessa situação degradante que configura a invisibilidade de pessoas apátridas, podemos inferir que a própria existência da apatridia é uma grave violação à dignidade da pessoa humana e ao art. $15^{\circ}$ da Declaração Universal dos Direitos Humanos de 1948 (DUDH), pois esse documento declaratório traz como preceito o direito à nacionalidade e a consequente não privação desse direito, conforme se destaca em: "1. Toda pessoa tem direito a ter uma nacionalidade. 2.Ninguém pode ser arbitrariamente privado da sua nacionalidade nem do direito de mudar de nacionalida de (ONU, 1948).

É importante lembrar que os direitos humanos determinam valores de natureza universal e, por isso, a Carta Declaratória preceitua que a aplicabilidade e o gozo dos direitos independem de qualquer distinção entre as pessoas humanas, pois todos nascemos livres e iguais nos termos da lei. Nesse sentido:

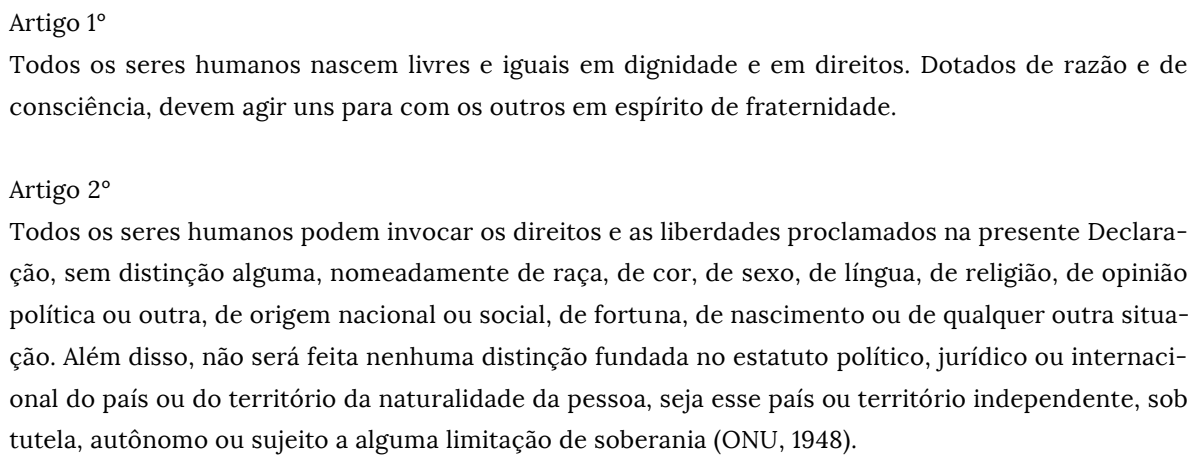
ção, sem distinção alguma, nomeadamente de raça, de cor, de sexo, de língua, de religião, de opinião política ou outra, de origem nacional ou social, de fortuna, de nascimento ou de qualquer outra situação. Além disso, não será feita nenhuma distinção fundada no estatuto político, jurídico ou internacional do país ou do território da naturalidade da pessoa, seja esse país ou território independente, sob tutela, autônomo ou sujeito a alguma limitação de soberania (ONU, 1948).

A respeito desses valores proclamados pela DUDH, destacamos que, discursivamente, são evocadas vozes que configuram a categoria do hiperenunciador, como propõe Maingueneau (2008), pois essas vozes declaratórias carregam a historicidade reflexiva de certos enunciados ditos em épocas passadas. Esses saberes circulantes são reveladores de máximas jurídicas e de aforismos de alcance moral empregados nas lutas coletivas pelos direitos à igualdade e à liberdade proclamados desde o período iluminista francês.

Lembramos que Maingueneau (2010) apresenta a noção de aforização para tratar de um tipo específico de enunciados que supostamente surgem sem a estrutura textual. Para o linguista francês, a aforização é caracterizada por ter um funcionamento enunciativo diverso daquele instituído na ou pela enunciação textualizante. Dito de outra forma, enunciados como provérbios, máximas, slogans, sentenças, frases feitas, entre outros, diferem da lógica de funcionamento de um texto e, por isso, fazem parte da cena aforizante.

Nessa dinâmica da aforização, ressaltamos o lema da Revolução Francesa que se centrou nos ideais de "Liberté, Égalité, Fraternité" defendidos pelos revolucionários em suas manifestações políticas que culminaram com a instalação da Assembleia Nacional da França. Essas máximas, como nos ensina Maingueneau (2008, 2010), muitas vezes são curtas e enunciam um sentido completo e bem- 


\section{REVISTA DA ABRALIN}

estruturado, de modo a impressionar gerações de interlocutores e, por isso, se tornam memorizáveis e reutilizáveis, pois transmitem uma "memória compartilhada" (MAINGUENEAU, 2008, p.104).

Dessa forma, o slogan "Liberdade, Igualdade, Fraternidade" é uma herança do século das Luzes, cujos valores se incorporam nos textos declaratórios de direitos e nas constituições de vários países. Ele foi inscrito na Constituição francesa de 1958 e hoje faz parte do patrimônio jurídico não apenas da França, mas do próprio sistema jurídico como se perfila no mundo ocidental.

De acordo com informações obtidas no portal do Élysée (acesso em: 6 set. 2021), os conceitos de "liberdade, igualdade e fraternidade" não foram inventados pela Revolução Francesa, mas a convergência desses conceitos - retomados de Rousseau e Locke - foi frequente na época do Iluminismo. Sem dúvida, vê-los unidos em um tríptico foi uma criação da força revolucionária francesa que os eternizou como máximas memoráveis, dado o potencial discursivo e simbólico dos valores ali evocados. A título de ilustração desse feito, é válido recordar que, em um discurso sobre a organização da Guarda Nacional, em dezembro de 1790, Robespierre propôs que as palavras "Le Peuple Français" e "Liberté, Égalité, Fraternité" fossem inscritas nos uniformes e nas bandeiras, mas seu projeto não foi adotado. No entanto, durante a Revolução de 1848, o lema foi definido como um princípio da República francesa, consagrado, inclusive, na Constituição do país.

Com base nesse breve panorama, é possível compreender a força do hiperenunciador que transporta esses valores republicanos por gerações de povos e territórios. Maingueneau (2008) esclarece que a figura do hiperenunciador está associada aos sistemas de "particitação". Esse termo pode ser compreendido como uma categoria discursiva composta de uma "palavra-valise" que une dois elementos: "participação" e "citação" (MAINGUENEAU, 2008, p. 93). Nas palavras do linguista francês:

Essa categoria fundamentalmente pragmática atravessa vários gêneros, sem que, para isso, corresponda a um procedimento. Mutatis mutandis, poder-se-ia dizer que se trata de um procedimento comparável ao dos linguistas que, seguindo a linha de Benveniste (1966), distinguem vários sistemas enunciativos (ao menos dois), segundo a relação que se estabelece entre enunciado e situação de enunciação (MAINGUENEAU, 2008, p. 93).

Muitas vezes esses movimentos de particitações reforçam a coesão de coletividades ou de grupos militantes que, com seus saberes circulantes, se opõem a uma situação exterior de natureza ameaçadora. A própria Declaração Universal dos Direitos Humanos (DUDH), como sabemos, surgiu após a $2^{\text {a }}$ Guerra Mundial. Com o término do conflito em 1945, diferentes países se reuniram para formar a Organização das Nações Unidas em 1948. O objetivo desse encontro era criar um ambiente plural e multilateral que pudesse garantir a paz entre as nações e o fortalecimento dos direitos humanos, com a finalidade de pôr fim aos horrores da guerra recém-terminada e para que estes não se repetissem. Foi nesse contexto que a DUDH foi concebida, para que, com base em seus preceitos, nenhum ser humano tivesse seus direitos violados.

Nessa dimensão de memórias compartilhadas, é importante lembrar que houve outras tentativas anteriores à DUDH para sistematizar quais seriam os direitos humanos. Entre elas, destacamos a Declaração dos Direitos do Homem e do Cidadão de 1789 da França e a Carta de Direitos de 1791 dos Estados Unidos, ambas sem o caráter universal da Declaração de 1948. No mesmo ano da DUDH, foi 


\section{REVISTA DA ABRALIN}

aprovada a Declaração Americana dos Direitos e Deveres do Homem, durante a conferência que criou a Organização dos Estados Americanos (OEA).

Desse panorama contextual, observamos que as vozes enunciadoras da Declaração Universal dos Direitos Humanos se imiscuem na figura coletiva da Assembleia Geral das Nações Unidas que, por sua vez, proclama a Carta de Valores, com o objetivo também de promover a aliança e o comprometimento dos Estados-membros sobre aquilo que se declara perante a comunidade internacional. Nesse sentido:

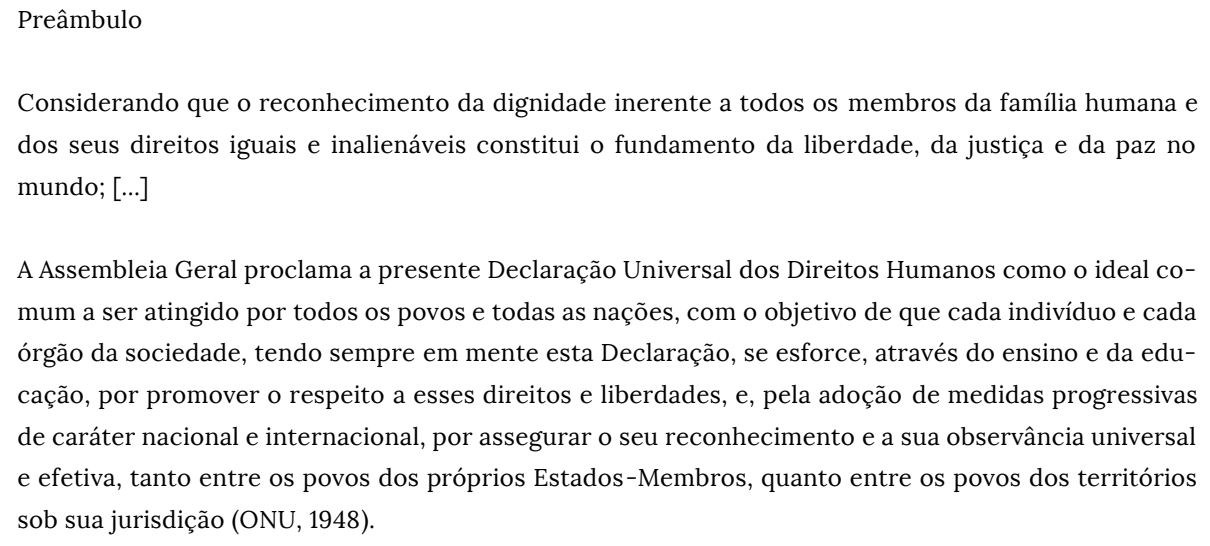
dos seus direitos iguais e inalienáveis constitui o fundamento da liberdade, da justiça e da paz no mundo; $[\ldots]$

A Assembleia Geral proclama a presente Declaração Universal dos Direitos Humanos como o ideal comum a ser atingido por todos os povos e todas as nações, com o objetivo de que cada indivíduo e cada órgão da sociedade, tendo sempre em mente esta Declaração, se esforce, através do ensino e da educação, por promover o respeito a esses direitos e liberdades, e, pela adoção de medidas progressivas de caráter nacional e internacional, por assegurar o seu reconhecimento e a sua observância universal e efetiva, tanto entre os povos dos próprios Estados-Membros, quanto entre os povos dos territórios sob sua jurisdição (ONU, 1948).

Nesse excerto, podemos verificar alguns momentos de retomada das vozes coletivas e das máximas compartilhadas que circularam na época da Revolução Francesa, como se fosse um eco que se instaurasse na composição do texto declaratório de 1948, cujo efeito parece rememorar os dizeres dos revolucionários, porém com a inclusão contemporânea que determina a "[...] observância universal e efetiva, tanto entre os povos dos próprios Estados-Membros, quanto entre os povos sob sua jurisdição" (ONU, 1948). Assim, destacamos que a proclamação da Assembleia Geral da ONU, desde o seu Preâmbulo, retoma os ideais revolucionários de "direitos iguais e inalienáveis" e "respeito a esses direitos e liberdades" como valores que integram a noção de "ideal comum".

É importante lembrar que essas máximas refletidas em valores como "ideal comum", "direitos inalienáveis", "respeito a direitos", "liberdade, igualdade e fraternidade" compõem, como afirmamos, enunciados que, em suas origens, supostamente emergiram descolados inicialmente de uma estrutura textual rígida que os unisse em um compósito declaratório. A natureza desses enunciados nos permite considerar a perspectiva aforizante desses saberes memoráveis e memorizáveis que passaram, posteriormente, a integrar a natureza panfletária dos revolucionários franceses e a consequente estruturação dos documentos declaratórios que se seguiram. Assim, a herança histórica desses enunciados reforça a lógica da obrigatoriedade dos direitos humanos e universais como se configura na contemporaneidade.

Dessa forma, as vozes coletivas, quando proclamaram a Declaração dos Direitos Humanos de 1948 (DUDH), se comprometeram a respeitar a dignidade humana e a promover a paz, para que todos os seres nascidos em diferentes territórios pudessem ter assegurados seus direitos e suas liberdades fundamentais, "[...] sem distinção alguma, nomeadamente de raça, de cor, de sexo, de língua, de 


\section{REVISTA DA ABRALIN}

religião, de opinião política ou outra, de origem nacional ou social, de fortuna, de nascimento ou de qualquer outra situação" (ONU, 1948). É fundamental mencionar que o Brasil se tornou signatário dessa Declaração desde que ela foi proclamada em 1948.

Isso posto, observamos que os anseios daqueles que integram a Assembleia Geral das Nações Unidas perfilam uma espécie de locutor coletivo que explicita sua adesão aos preceitos universais, compondo discursivamente "um tesouro de enunciados" (MAINGUENEAU, 2008, p. 94) indissociáveis e reveladores do compromisso assumido por essa coletividade como um ideal comum a ser alcançado por todos os povos e por todas as nações. É interessante notar que o ensino e a educação aparecem no texto declaratório como formas para viabilizar e garantir o respeito a esses direitos que compõem o "tesouro" da humanidade.

Para que possamos compreender as noções de "tesouro" e de "locutor" propostas em nosso estudo, destacamos as considerações de Maingueneau (2008), no excerto a seguir:

- $\quad$ O locutor que cita mostra sua adesão ao enunciado citado, que pertence àquilo que se poderia denominar um tesouro de enunciados de contornos mais ou menos fluidos, indissociável de uma comunidade onde esses enunciados circulam e que, precisamente, se define de maneira privilegiada por compartilhar tal tesouro. [...]

- $\quad$ Esse tesouro e a comunidade correspondente recorrem a um hiperenunciador cuja autoridade garante menos a verdade do enunciado - no sentido estrito de uma adequação a um estado de coisas do mundo -, e mais amplamente sua "validade", sua adequação aos valores, aos fundamentos de uma coletividade (MAINGUENEAU, 2008, p. 94-95, aspas do original).

É interessante observar o discurso de autoridade veiculado pela força enunciativa do hiperenunciador que garante a adesão de preceitos jurídicos a processos de validade, bem como a adequação de valores ao estado de coisas no mundo. Em outras palavras, a Declaração Universal dos Direitos Humanos apresenta uma composição discursiva que indica a legitimidade dos enunciados adequados às demandas e aos fundamentos do próprio sistema democrático contemporâneo. Dessa forma, acreditamos que o hiperenunciador assume, na DUDH, a voz de uma coletividade que busca reafirmar o compromisso declaratório a respeito de questões suscitadas pelo princípio da não discriminação e pelo direito a ter uma nacionalidade. Assim, essa voz coletiva inevitavelmente evoca as memórias das lutas passadas contra os sistemas de opressão e, ao mesmo tempo, sinaliza a prospecção de um tempo presente/futuro que ainda se apresenta vigilante diante dos desafios. O direito a ter uma nacionalidade parece ser um desses desafios que ainda circulam em nossos territórios e para os quais há reduzido campo de ação, se considerarmos a dimensão global.

Acreditamos que a complexidade da apatridia pode ser definida como uma situação migratória que escancara a desigualdade social e evidencia a condição de invisibilidade da pessoa humana. Os apátridas muitas vezes permanecem no limbo da marginalização e, por isso, se tornam invisíveis e desconhecidos perante o corpo social em que se encontram. Como afirmamos, o artigo $15^{\circ}$ da Declaração Universal dos Direitos Humanos de 1948 determina que todas as pessoas têm direito a ter uma nacionalidade. Em linhas gerais, a nacionalidade pode ser adquirida com base no nascimento registrado no território de um país, tendo em vista o laço de parentesco, ou a naturalização após o casamento com um cidadão de determinado Estado soberano. A naturalização também pode ser 


\section{REVISTA DA ABRALIN}

concedida em situações de residência com duração definida na legislação respectiva ou por outras razões específicas. As regras são diferentes e há variações de uma nação para outra.

Existem duas convenções das Nações Unidas que tratam especificamente dos apátridas: a Convenção sobre o Estatuto dos Apátridas, de 1954, e a Convenção sobre a Redução dos Casos de Apatridia, de 1961. Entretanto, apenas 62 países ratificaram a primeira, e a segunda foi ratificada por somente 34 nações. Alguns apátridas são também considerados refugiados, embora essa situação não aconteça na maioria dos casos. A privação da nacionalidade, na maioria das vezes, faz parte de um processo doloroso de perseguição de pessoas ou grupos sociais que são obrigados a fugir de seus territórios. A apatridia pode também acontecer como punição em razão de uma fuga. No entanto, segundo dados do Alto Comissariado das Nações Unidas para os Refugiados (ACNUR), "[...] muitos apátridas não são vítimas de perseguição (e nunca tiveram de deixar suas casas) e muitos refugiados conservam a sua nacionalidade, durante toda sua dolorosa experiência no estrangeiro" (ONU BRASIL, acesso em: 24 ago. 2021).

\section{Narrativas de vida de pessoas em situação de fluxos migratórios}

Essa dimensão reflexiva dos apátridas se deslocou também para a autopercepção das identidades dos sujeitos participantes da conversa deste estudo, pois eles apresentaram, durante as discussões sobre a invisibilidade social, as suas próprias narrativas de vida como estrangeiros residentes no Brasil. Certamente, a apatridia desperta reflexões sobre processos identitários sensíveis que caracterizam modos de vida de pessoas vulneráveis em suas diversas formas de manifestação, especialmente na condição de refugiados, pois esse segmento requer uma análise mais cuidadosa, em razão da própria natureza do mundo em constante mudança. Lembramos que os alunos do PLAc são, de modo geral, estrangeiros que viviam em situação de vulnerabilidade social em seus países de origem, conforme dados do Relatório Parcial de Cumprimento de Objeto referente ao ano de 2020, disponibilizado pela SRI, em 4 de março de 2021, como afirmamos. É válido mencionar que muitos desses alunos ainda enfrentam diversas dificuldades no Brasil que, muitas vezes, geram sentimentos de invisibilidade ou estranhamento.

Dessa forma, discutir o tema da apatridia é fundamental nesses núcleos de estudantes estrangeiros, pois certamente contribui para melhor compreensão da legislação vigente sobre essa temática. Lembramos ainda que o processo de naturalização nesses casos, de acordo com as leis brasileiras, passa por um trâmite diferenciado que, muitas vezes, é desconhecido por aqueles que mais necessitam da tutela jurídica. O PLAc, em sua abordagem de ensino da língua portuguesa como acolhimento, certamente presta um serviço social relevante, durante as atividades de conversação, ao explicitar a natureza jurídica dos apátridas e as proteções jurídicas previstas em lei. 


\section{REVISTA DA ABRALIN}

Feito esse panorama, antes de prosseguir com alguns dos relatos dos alunos do PLAc, gostaríamos de explicitar também a importância das narrativas de vida para os estudos discursivos, especialmente, quando analisamos processos identitários e suas implicações em modos de vida na sociedade. Conforme esclarece a pesquisadora brasileira Ida Lucia Machado (2016, p. 121), “[...] a posição assumida por um eu-narrador ao contar parte de sua vida" nunca é una e sim construída pelo complexo enunciativo de outras vozes discursivas ou fragmentos de vozes que tocam as reflexões do sujeito-que-se-narra. Dessa forma, "[...] a identidade de um sujeito-narrador se constrói graças à curiosa mescla entre o individual e o social" (MACHADO, 2016, p. 121). Lembramos que a abordagem de Machado (2016) sobre o sintagma "narrativa de vida" tem sua origem na tradução que fez do termo récit de vie, proposto por Bertaux (1997).

O conceito de récit de vie originou-se nas Ciências Sociais e teve como precursores dois sociólogos da Escola de Chicago, William Thomas e Florian Znanieckzi, autores da obra The Polish peasant in Europe and America: monograph of an immigrant group. Posteriormente, essa metodologia foi desenvolvida na França, pela visada do sociólogo Daniel Bertaux (1997), com base em uma perspectiva etnossociológica, que se propunha a

[...] estudar um fragmento particular de realidade social-histórica, um objeto social; compreender como ele funciona e como ele se transforma, ressaltando as configurações das relações sociais, os mecanismos, os processos, as lógicas de ação que o caracterizam (BERTAUX, 1997, p. 7, tradução nossa, itálico do autor $)^{9}$.

Conforme esclarece Carvalho (2016), esse "[...] fragmento particular de realidade social-histórica", definido por Bertaux (1997, p. 7),

[...] corresponde a um determinado grupo de pessoas inseridas em um mesmo universo profissional. Tais pessoas vivem, de certo modo, situações sociais semelhantes e compartilham não só as habilidades necessárias para desempenhar suas funções, mas compartilham também modos de divisão do trabalho, valores e crenças. Bertaux (1997) denomina tais fragmentos de "mundos sociais" (CARVALHO, 2016, p. 23).

Dessa forma, Bertaux (1997) sugere uma metodologia que tem como ponto de partida a interação face a face entre o pesquisador e o entrevistado. Os participantes são convidados a narrar sua vida ou partes dela, destacando determinados aspectos, de acordo com as orientações indicadas pelo pesquisador. Para se referir a essa prática metodológica, o sociólogo propõe a expressão récit de vie, traduzida, como foi visto, para o português como narrativa de vida.

A respeito dos estudos sobre narrativas de vida, destacamos também os trabalhos desenvolvidos pela pesquisadora brasileira Glaucia Muniz Proença Lara (2021), que tem apresentado pesquisas sobre narrativas de pessoas em contextos migratórios. Em seu artigo "De migrantes a cidadãos do mundo: narrativas de vida de brasileiros no continente europeu", Lara (2021) examina e compara, à

\footnotetext{
${ }^{9}$ No original: [...] étudier un fragment particulier de la réalité sociale-historique, un objet social; de comprendre comment il fonctionne et comment il se transforme, en mettant l'accent sur les configurations de rapports sociaux, les mécanismes, les processus, les logiques d'action qui le caractérisent.].
} 


\section{REVISTA DA ABRALIN}

luz de categorias da Análise do Discurso Francesa (ADF), três narrativas de vida de migrantes brasileiros que foram coletadas por meio de entrevistas. Em sua abordagem, a pesquisadora busca apreender as representações (de si, dos outros e do mundo) que esses sujeitos constroem por meio do ato de dizer em situação de interação.

A interatividade também foi praticada por nós durante a conversa que tivemos com os alunos estrangeiros do CEFET-MG, embora a operacionalidade metodológica da conversação tenha ocorrido pelos mecanismos virtuais do Ensino Remoto Emergencial (ERE), o que de certa forma aproxima as relações humanas, nestes tempos de pandemia, mas também distancia o contato interativo oriundo dessas relações. Em determinado momento da nossa conversa com os alunos do PLAc, projetamos a seguinte citação de Bauman:

Refugiados da bestialidade das guerras, dos despotismos e da brutalidade de uma existência vazia e sem perspectivas têm batido à porta de outras pessoas desde o início dos tempos modernos. Para quem está por trás dessas portas, eles sempre foram - como o são agora - estranhos. Estranhos tendem a causar ansiedade por serem "diferentes" - e, assim, assustadoramente imprevisíveis, ao contrário das pessoas com as quais interagimos todos os dias e das quais acreditamos saber o que esperar (BAUMAN, 2017 , p. 8 , aspas do original).

Com base nesse excerto e na contextualização sobre o sentimento de estranhamento, provocamos o início da nossa conversa com algumas reflexões: "nesta conferência sobre direitos e deveres em tempos de fluxos migratórios, queremos evocar o direito a não sermos invisíveis, o direito a sermos reconhecidos nas particularidades das nossas identidades e na dignidade humana que compõe a morada do ser" (FIGUEIREDO, 2021). A partir dessa reflexão introdutória, direcionamos algumas indagações aos alunos imigrantes: "quem seriam os estranhos à nossa porta? Como poderíamos explicar esse sentimento de estranhamento? Em outras palavras, vocês já se sentiram como estranhos aqui no Brasil"? (FIGUEIREDO, 2021). Dessa indagação, surgiram alguns relatos. Entre eles, destacamos:

Posso dizer que sim. No começo, eu me sentia estranho. Já percebia isso no olhar das pessoas para mim. Na forma como você fala, sabe? No olhar... o que é esta pessoa? Mas agora não sinto isso, como era no começo (PARTICIPANTE A, 2021) ${ }^{10}$.

Com base nessa declaração do nosso aluno imigrante, perguntamos ainda:

O que você acha que foi marcante na sua história de vida para que você não se sentisse mais como um estranho? Ou seja, o que foi determinante, na sua opinião, para que você saísse dessa condição de um "estranho batendo à nossa porta" e passasse a se sentir como um ser integrado em nossa sociedade? (FIGUEIREDO, 2021).

O participante A nos deu a seguinte resposta:

\footnotetext{
${ }^{10}$ Esclarecemos que as falas dos participantes foram transcritas exatamente como foram registradas a partir da oralidade.
} 


\section{REVISTA DA ABRALIN}

Acho que é o fato de... se esforçar para entender a cultura e também quanto mais a gente sai pra fora, aprende... a gente se sente parte da sociedade. No começo, a gente tem um pouco de... não sei, de se sentir como numa bolha... mas obviamente isso vai mudando também (PARTICIPANTE A, 2021).

Nesse diálogo com o participante A, percebemos aquilo que Charaudeau (2015, p. 18) nomeou de "mecanismo de construção identitária". Inspirado na fenomenologia e na psicologia social, o linguista francês discorre sobre a noção de sujeito e afirma que para uma "[...] tomada de consciência identitária, é necessário que se perceba uma diferença e que se estabeleça uma certa relação face ao outro" (CHARAUDEAU, 2015, p. 18, itálicos do autor). Assim, a percepção da diferença do outro constitui a prova discursiva da tomada de consciência da própria existência do "eu" diante da alteridade.

Esse movimento de "atração" das diferenças, conforme propõe Charaudeau (2015), nos parece esclarecer a maneira como o participante A se descobre em território brasileiro. Pelos relatos explicitados, o sentimento de estranhamento aos poucos vai passando, porque a cultura brasileira passa a ser também observada e compreendida por esse ser-que-se-narra. Esse ato de mergulhar ou de "se esforçar para entender a cultura", como afirmou o participante A, evidencia um necessário compartilhamento de sentidos para que se instaure a construção de um sentimento real de pertencimento social. Nesse compósito de sentidos, observamos ainda aquilo que Machado (2016) nos disse sobre a identidade do sujeito-narrador que, ao contar parte de sua vida, produz um movimento identitário que, inevitavelmente, mescla o componente individual e o social do qual participa.

É importante esclarecer que a noção de pertencimento passa a integrar o processo identitário desse sujeito imigrante, mas sem se sobrepor aos traços identitários que definem o "eu" dessa pessoa fora de seu território de origem. Essa percepção nos parece clara, quando o participante A afirma: "quanto mais a gente sai pra fora, aprende... a gente se sente parte da sociedade". Há uma autopercepção da condição de estar fora do território de origem e dos deveres que esse movimento implica, como o de saber a língua e a cultura do país. No entanto, há também uma inferência de que esse "eu" se reconhece como um sujeito com suas especificidades identitárias em uma situação de fluxo migratório ("a gente sai pra fora"). Às vezes, essas particularidades sinalizam o sentimento de que eles (os imigrantes) vivem em "bolhas", segundo nos relatou o participante A. Essa declaração de se sentir em uma bolha parece indicar uma metáfora que sinaliza o efeito da solidão, ou o sentimento de ser diferente em uma terra que, por sua vez, já começa a fazer parte também de suas próprias histórias de vida.

A respeito desse sentimento de "se sentir como numa bolha", trouxemos outro fragmento da obra de Bauman para a nossa conversa, momento em que a voz discursiva do sociólogo polonês mencionou a sua abordagem sobre o "viver em bolhas de sabão". Embora a visão de Bauman seja diferente daquela relatada pelo participante $\mathrm{A}$, consideramos interessante a explicitação do excerto seguinte com a finalidade de enriquecer o nosso debate, para que pudéssemos pensar essa noção de "bolha" em diferentes perspectivas. Vejamos:

A cultura do conforto, que nos faz pensar apenas em nós mesmos, nos torna insensíveis aos gritos de outras pessoas, faz-nos viver em bolhas de sabão que, embora adoráveis, carecem de substância; oferecem uma ilusão efêmera e vazia que resulta na indiferença em relação aos outros; na verdade, leva até a globalização da indiferença. Neste mundo globalizado, caímos na indiferença globalizada. Nós 


\section{REVISTA DA ABRALIN}

nos acostumamos ao sofrimento dos outros. Ele não me afeta. Não me diz respeito. Não é da minha conta! (BAUMAN, 2017, p. 16-17).

Nessa passagem da obra de Bauman, percebemos o trânsito da voz discursiva entre universos identitários que nos parecem diferentes para a compreensão do sentimento propagado pela "bolha de sabão". Por um lado, reconhecemos a voz do sociólogo, quando teoriza sobre a "cultura do conforto" e sobre as noções de "globalização da indiferença" e de "indiferença globalizada". Por outro, identificamos, no fragmento citado, a inscrição de um "eu" / "nós" que indica as narrativas de um sujeito enunciador que, por sua vez, também faz um relato de si ou da forma automatizada que se incorpora a suas ações diante do mundo. Essa voz nos faz pensar, ainda, nesse "eu" que pode ser incorporado por todos nós, cidadãs e cidadãos de diferentes territórios que, muitas vezes, se tornam insensíveis ao grito ou à dor alheia, em razão da "cultura do conforto".

Essa visada de Bauman nos fez recordar também a noção de "imaginários socioculturais", como propõe Charaudeau (2015). O "viver em bolhas", tanto na visão de isolamento (cultura do conforto) quanto na dimensão da solidão (sentir-se excluído), gera uma reflexão sobre o encontro de si com o outro. De acordo com Charaudeau (2015), esse encontro

[...] se realiza não apenas por meio de ações que os indivíduos praticam na vida em sociedade, mas também por meio de seus julgamentos sobre a legitimidade dessas ações, de si e dos outros, isto é, por meio de suas representações. Essas representações evidenciam imaginários coletivos que são produzidos pelos indivíduos que vivem em sociedade, imaginários esses que manifestam, por sua vez, valores por eles compartilhados, nos quais eles se reconhecem e que constituem sua memória identitária (CHARAUDEAU, 2015, p. 21, itálicos do autor).

O julgamento que se faz do outro, em situações diversas, especialmente naquelas que compõem a vida cotidiana, produz um jogo de representações que nem sempre é adequado ou agradável, quando se trata de processos identitários em situações de imigração. Na narrativa seguinte, podemos observar essa relação, às vezes tensa, entre representações e imaginários coletivos.

\footnotetext{
Acho que cada vez que vou entrar no UBER, o motorista depois de... talvez, duas perguntas, ele vai saber, pelo meu sotaque, você é brasileira não? Eu falo: não, (risos). Sempre que vou ir pro mercado ou em lugar desconhecido sempre vou estar estranha pra eles, sabe? Nunca... no país..., acho que a gente já se acostumou, né? Mas cada vez que você vai encontrar as pessoas novas, vai ser sempre estranha pra eles. [...] Eu quero contar! Primeiro, quando eu chego no Brasil, eu não sabia português e sempre quando eu fui lá nos supermercados, e todo mundo que falava...oh, japonês, japonês... Mas eu!? (risos) não vim do Japão, né? Eu falo com eles, eu sou da Indonésia. E eles começaram a falar palavras japonesas assim: arigatô. Ai, meu Deus! Ele que achou a minha língua da Indonésia... e já põe o japonês ou chinês... eu não entende não. Muito estranho, mas agora... já... interessante pra mim (PARTICIPANTE B, 2021).
}

No relato citado, verificamos o sentimento de estranhamento em uma situação ambivalente. Por um lado, há a generalização do olhar do outro que, ao estranhar o sotaque da pessoa imigrante, provoca um movimento de julgamento ao atribuir ao estrangeiro uma representação identitária, no caso, a representação do japonês como elemento generalizante da identidade do oriental. Por outro lado, há o sentimento desconfortável da imigrante ao ser comparada de forma jocosa com o japonês 


\section{REVISTA DA ABRALIN}

ou o chinês. Esse sentimento é marcado pela explosão discursiva da expressão dêitica: "Eu quero contar!" aquilo que me aconteceu ali, quando cheguei ao Brasil. Sobre a dêixis recordamos que estamos empregando a abordagem discursivo-referencial (MAINGUENEAU, 2016, p. 147). O referente é, assim, determinado em relação à identidade ou à situação de interlocução.

A declaração da participante B sinaliza também o relevante movimento da narrativa de vida para esse ato necessário e urgente de se contar uma experiência. Além disso, mostra como esse ato pode se revelar uma espécie de catarse das situações vividas, especialmente, quando estas implicam dor, desconforto, solidão ou incompreensão.

Ao longo do relato da participante B, observamos ainda o desconforto provocado pelo estranhamento em situações da vida cotidiana, dada a generalização feita pelas pessoas em ambientes diferentes, no mercado, no UBER e em outras situações. O relato da participante B parece indicar, em síntese, a sua percepção de que "sempre vou estar estranha pra eles", embora essa perspectiva, com o tempo, ganhe certo contorno de resiliência e adaptação.

\section{Considerações finais}

A nossa conversa com os alunos imigrantes do CEFET-MG nos possibilitou vivenciar o relato de si, ou as narrativas de vida, como estratégia de compreensão discursiva dos processos identitários em fluxos migratórios. Reconhecemos a relevância das interlocuções que fizemos para a liberação não apenas das vozes discursivas em uma aula de conversação do PLAc, mas especialmente para a compreensão dessas pessoas sobre suas próprias histórias de vida em um novo país, nas quais se misturam os sentimentos de estranhamento, resiliência, compreensão e entrega a um universo linguístico e cultural que passa a fazer parte das experiências daqueles-que-se-narram.

Durante a nossa exposição, apresentamos alguns dados e conceitos sobre os apátridas e fizemos uma longa discussão sobre os sentimentos de invisibilidade e solidão que fazem parte da vida cotidiana de pessoas em situação de migração. Buscamos fundamentar as nossas ideias com base na legislação e nos tratados internacionais vigentes sobre a apatridia. Além disso, refletimos discursivamente sobre alguns preceitos da Declaração Universal dos Direitos Humanos de 1948 que explicitam, entre outros, os direitos à igualdade, à liberdade, à fraternidade e também à nacionalidade. Buscamos demonstrar que esses preceitos fazem ressoar ecos e máximas de lutas passadas que nos são caras para a (re)definição dos desafios do tempo presente.

Nessa caminhada, percebemos a relevância da abordagem transdisciplinar que praticamos, pois os diálogos entre o Direito, a Teoria Social e a Análise do Discurso foram imprescindíveis para a criação de situações de interlocução que geraram reflexões necessárias sobre o universo do estrangeiro e seu contato com a língua e a cultura brasileiras. Por meio desse entrecruzamento metodológico, num evento que mesclou conversação e palestra, observamos uma reflexão profunda dos estudantes sobre a noção do "estranho à nossa porta", como sinalizou Bauman, em diferentes perspectivas. Além disso, identificamos formas de enfrentamento ao estranhamento encontradas pelos 


\section{REVISTA DA ABRALIN}

sujeitos participantes e apresentadas durante seus relatos, entre as quais destacamos o direito à não invisibilidade evocado pelos participantes. Em outras palavras, os alunos do PLAc explicitaram a habilidade linguística necessária para pleitear o direito a ser reconhecido e respeitado como pessoa, com suas particularidades, em situações de igualdade social, ainda que haja diferenças.

\section{Agradecimentos}

Agradeço à professora Glaucia Muniz Proença Lara pela presença nessa roda de conversa que tivemos com os estrangeiros, no dia 5 de agosto de 2021, e também pelo incentivo à escrita deste texto. Agradeço à equipe de conversação do PLAc, às professoras coordenadoras do PLE, Luciana Aparecida Silva de Azeredo (DELTEC) e Maria Cristina Ramos de Carvalho (SRI), e aos servidores da Secretaria de Relações Internacionais (SRI) do CEFET-MG pelo apoio a esta pesquisa e pela declaração de autorização de uso dos dados coletados neste estudo.

\section{REFERÊNCIAS}

AGIER, Michel. Managing the Undesirables. Malden: Polity, 2011.

BARBOSA, S. D. P. Igualdade. In: DINIZ, I. C. S.; GOMES, L. S. (Orgs.) Vozes: eu ele nós: Literatura e Direitos Humanos. Belo Horizonte: CEFET-MG, 2017. p. 41-42.

BAUMAN, Z. Estranhos à nossa porta. Rio de Janeiro: Zahar. Edição do Kindle, 2017.

BERGER, P., LUCKMANN Th. Die gesellschaftliche Konstruktion der Wirklichkeit. Frankfurt an Main, 1966.

BERTAUX, D. Les récits de vie. Collection 128. Paris: Nathan, 1997.

BRASIL. Constituição da República Federativa do Brasil, 1988. Texto Constitucional de 5 de outubro de 1988 com as alterações adotadas pela emenda constitucional $n^{\circ}$ 111, de 28 de setembro de 2021. Brasília: Senado Federal. Disponível em: http://www.planalto.gov.br/ccivil_03/constituicao/constituicao.htm. Acesso em: 1 out. 2021.

BRASIL. Decreto $n^{\circ}$ 9.199, de 20 de novembro de 2017. Regulamenta a Lei nº 13.445, de 24 de maio de 2017, que institui a Lei de Migração. Diário Oficial [da] República Federativa do Brasil. Brasília, DF, 20 nov. 2017. Disponível em: http://www.planalto.gov.br/ccivil_03/_ato2015-2018/2017/decreto/d9199.htm. Acesso em 19 ago. 2021.

BRASIL. Lei nº 10.406, de 10 de janeiro de 2002. Institui o Código Civil. Diário Oficial [da] República Federativa do Brasil. Brasília, DF, 10 jan. 2002. Disponível

em: http://www.planalto.gov.br/ccivil_03/leis/2002/L10406compilada.htm. Acesso em 1 out. 2021.

BRASIL. Lei $n^{\circ}$ 13.445, de 24 de maio de 2017. Institui a Lei de Migração. Diário Oficial [da] República Federativa do Brasil. Brasília, DF, 25 mai. 2017. Disponível em: http://www.planalto.gov.br/ccivil_03/_ato2015-

2018/2017/lei/L13445.htm. Acesso em: 19 ago. 2021. 


\section{REVISTA DA ABRALIN}

CARVALHO, A. T. S. Relações teórico-metodológicas entre a AD e a narrativa de vida. In: MACHADO, I, L.; melo, M. S. S. (Orgs.). Estudos sobre narrativas em diferentes materialidades discursivas na visão da Análise do Discurso. Belo Horizonte: Núcleo de Análise do Discurso, FALE/UFMG, 2016. p. 21-42.

CEFET-MG. AUTORIZAÇÃO Nº5/2021-SRI (11.49). Nº do Protocolo: 23062.039900/2021-51. A coordenação do Programa Português como Língua Estrangeira do CEFET-MG (PLE) autoriza a professora Adriana do Carmo Figueiredo a utilizar dados relativos ao curso de Português como Língua de Acolhimento (PLAc), mediante não identificação dos alunos estrangeiros.

CHARAUDEAU, P. Identidade linguística, identidade cultural: uma relação paradoxal. In: LARA, G. P.; LIMBERTI, R. P. (Orgs.). Discurso e (des)igualdade social. São Paulo: Contexto, 2015. p. 13-29.

CHARAUDEAU, P. Langage et discours : éléments de sémiolinguistique. Paris: Hachette, 1983.

ÉLYSÉE. Portal francês que apresenta informações sobre os símbolos da França e outras notícias. Disponível em: https://www.elysee.fr/la-presidence/les-symboles-de-la-republique-francaise. Acesso em: 06 set. 2021.

EQUIPE DE CONVERSAÇÃO PLE/PLAC - CEFET-MG. (plac.cefet@gmail.com). Relatório Parcial de Cumprimento de Objeto - Ano de 2020 [mensagem pessoal]. Mensagem recebida por acfigueiredo.prof@gmail.com em 04 ago. 2021.

FIGUEIREDO, A. C. Direitos e deveres em tempos de fluxos migratórios: uma leitura da obra Estranhos à nossa porta de Zygmunt Bauman. Conversação/Palestra (Curso de Português como Língua de Acolhimento - PLAc) Secretaria de Relações Internacionais (SRI), CEFET-MG, Belo Horizonte, 2021.

FIGUEIREDO, A. C. Narrativas de vida de Antígona (Sófocles), Sor Juana e Olympe de Gouges: a Justiça no divã da Análise do Discurso. Orientadora: Dra. Ida Lucia Machado, 2020. 300 f. Tese (Doutorado em Estudos Linguísticos - PosLin). Faculdade de Letras (FALE), Universidade Federal de Minas Gerais, Belo Horizonte, 2020.

HABERMAS, J. O discurso filosófico da modernidade: doze lições. Trad. Luiz Sérgio Repa. Rodnei Nascimento. São Paulo: Martins Fontes. 2000.

LARA, G. M. P. De migrantes a cidadãos do mundo: narrativas de vida de brasileiros no continente europeu. Caderno de Letras, Pelotas, n. 40, p. 275-301, maio-ago. 2021.Disponível em: https://periodicos.ufpel.edu.br/ojs2/index.php/cadernodeletras/article/view/20436. Acesso em 2 out. 2021.

MACHADO, I. L. Nos bastidores da Narrativa de vida \& Análise do Discurso. In: MACHADO, I.L. e MELO, M.S.S. (org.). Estudos sobre narrativas em diferentes materialidades discursivas na visão da Análise do Discurso. Belo Horizonte: NAD/FALE/UFMG, 2016, p. 121-138.

MAINGUENEAU, D. Aforização - enunciados sem texto?. Tradução: Ana Raquel Motta. In: MAINGUENEAU, D. Doze conceitos em Análise do Discurso. Organização: Sírio Possenti, Maria Cecília Perez de Souza-e-Silva. São Paulo: Parábola, 2010. p. 9-24.

MAINGUENEAU, D. Cenas da enunciação. Organização: Sírio Possenti, Maria Cecília Perez de Souza-e-Silva. São Paulo: Parábola, 2008.

MAINGUENEAU, D. Dêitico. In: CHARAUDEAU, P.; MAINGUENEAU, D. (Orgs.). Dicionário de análise do discurso. Coordenação da tradução Fabiana Komesu. 3.ed., $2^{a}$ reimpressão. São Paulo: Contexto, 2016. p. 147.

MAINGUENEAU, D. Enunciação. In: CHARAUDEAU, Patrick; MAINGUENEAU, Dominique (Orgs.). Dicionário de análise do discurso. Coordenação da tradução Fabiana Komesu. 3. ed., 2ª reimpressão. São Paulo: Contexto, 2016. p. 193-195. 


\section{REVISTA DA ABRALIN}

MINISTÉRIO DA JUSTIÇA E SEGURANÇA PÚBLICA. Ministério da Justiça e Segurança Pública reconhece 16 estrangeiros como apátridas. Publicado em 13/07/2020, às 09h42. Disponível em: https://www.gov.br/mj/pt$\mathrm{br} /$ assuntos/noticias/ministerio-da-justica-e-seguranca-publica-reconhece-16-estrangeiros-como-apatridas. Acesso em: 05 set. 2021.

NAÇÕES UNIDAS BRASIL (ONU BRASIL). Os Excluídos: o Mundo Desconhecido dos Apátridas. Brasília, DF, 26 abr. 2007. Disponível em: https://brasil.un.org/pt-br/54714-os-excluidos-o-mundo-desconhecido-dos-apatridas. Acesso em: 19 ago. 2021.

ORGANIZAÇÃO DAS NAÇÕES UNIDAS (ONU). Convenção sobre a Redução dos Casos de Apatridia. Nova Iorque, 1961. Feita em Nova York, em 30 de agosto de 1961. Entrada em vigor: 13 de dezembro de 1975, em conformidade com o Artigo 18. Texto: Documento das Nações Unidas A/CONF.9/15, 1961. Disponível em: encurtador.com.br/LQV07. Acesso em: 06 set. 2021.

ORGANIZAÇÃO DAS NAÇÕES UNIDAS (ONU). Convenção sobre o Estatuto dos Apátridas. Nova Iorque, 1954. Adotada em 28 de setembro de 1954 por uma Conferência de Plenipotenciários convocada pelo Conselho Econômico e Social em sua resolução 526 A (XVII), de 26 de abril de 1954. Entrou em vigor em 6 de junho de 1960, conforme o artigo $39^{\circ}$. Disponível em: encurtador.com.br/hnH08. Acesso em: 06 set. 2021.

ORGANIZAÇÃO DAS NAÇÕES UNIDAS (ONU). Declaração Universal dos Direitos Humanos. Paris, 1948. Proclamação pela Assembleia Geral das Nações Unidas em Paris, através da Resolução 217 A (III) da Assembleia Geral. Disponível em: https://www.ohchr.org/EN/UDHR/Documents/UDHR_Translations/por.pdf. Acesso em: 12 jul. 2018.

PARTICIPANTE A; PARTICIPANTE B. Relatos de alunos do PLAc. In: FIGUEIREDO, A. C. Direitos e deveres em tempos de fluxos migratórios: uma leitura da obra Estranhos à nossa porta de Zygmunt Bauman. Relatos orais (Curso de Português como Língua de Acolhimento - PLAc) - Secretaria de Relações Internacionais (SRI), CEFETMG, Belo Horizonte, 2021.

SALMON, C. Storytelling. La machine à fabriquer les images et à formater les esprits. Paris: La Découverte, 2007.

SECRETARIA DE RELAÇÕES INTERNACIONAIS DO CEFET-MG (SRI). Apresenta informações sobre o curso de Português como Língua de Acolhimento e de Cultura Brasileira para refugiados, portadores de visto humanitário e imigrantes em situação de vulnerabilidade social. Disponível em: https://www.sri.cefetmg.br/turmas-de-plac20172. Acesso em: 02 set. 2021 